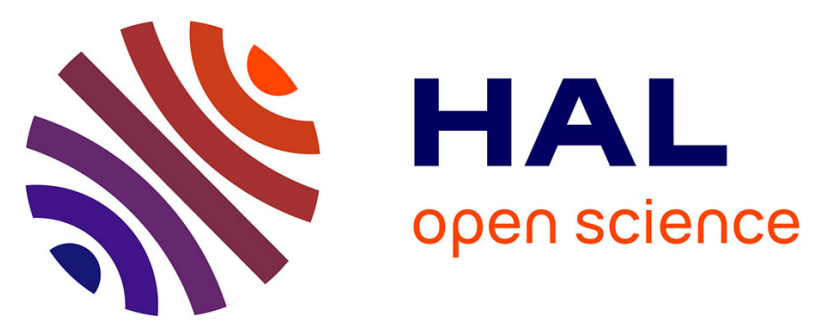

\title{
The Alleret Maar (Massif Central, France): A New Lacustrine Sequence of the Early Middle Pleistocene in Western Europe
}

Jean-François Pastre, Agnès Gauthier, Sébastien Nomade, Paul Orth, Ana Andrieu, Franck Goupille, Hervé Guillou, Stéphane Kunesch, Stéphane Scaillet, Paul Randall Renne

\section{To cite this version:}

Jean-François Pastre, Agnès Gauthier, Sébastien Nomade, Paul Orth, Ana Andrieu, et al.. The Alleret Maar (Massif Central, France): A New Lacustrine Sequence of the Early Middle Pleistocene in Western Europe. Comptes Rendus Géoscience, 2007, 339 (16), pp.987-997. 10.1016/j.crte.2007.09.019 . hal02478052

\section{HAL Id: hal-02478052 \\ https://hal.science/hal-02478052}

Submitted on 12 Oct 2020

HAL is a multi-disciplinary open access archive for the deposit and dissemination of scientific research documents, whether they are published or not. The documents may come from teaching and research institutions in France or abroad, or from public or private research centers.
L'archive ouverte pluridisciplinaire HAL, est destinée au dépôt et à la diffusion de documents scientifiques de niveau recherche, publiés ou non, émanant des établissements d'enseignement et de recherche français ou étrangers, des laboratoires publics ou privés. 
Surface geosciences (Palaeoenvironment)

\title{
The Alleret maar (Massif Central, France): A new lacustrine sequence of the early Middle Pleistocene in western Europe
}

\author{
Jean-François Pastre ${ }^{\mathrm{a}, *}$, Agnès Gauthier ${ }^{\mathrm{a}}$, Sébastien Nomade ${ }^{\mathrm{b}}$, Paul Orth ${ }^{\mathrm{a}}$, \\ Ana Andrieu ${ }^{a}$, Franck Goupille ${ }^{\mathrm{a}}$, Hervé Guillou ${ }^{\mathrm{b}}$, Stéphane Kunesch ${ }^{\mathrm{a}}$, \\ Stéphane Scaillet ${ }^{\mathrm{b}}$, Paul Randall Renne ${ }^{\mathrm{c}}$

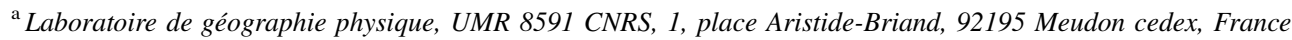 \\ ${ }^{\mathrm{b}}$ Laboratoire des sciences du climat et de l'environnement, CEA/CNRS, avenue de la Terrasse, 91198 Gif-sur-Yvette cedex, France \\ ${ }^{\mathrm{c}}$ Berkeley geochronology center, 2455, Ridge road, Berkeley, CA 94709, USA \\ Received 4 June 2007; accepted after revision 24 September 2007 \\ Available online 26 November 2007 \\ Presented by Georges Pédro
}

\begin{abstract}
The Alleret maar (Massif Central, France) provides a long lacustrine sequence (40.6 m) attributed to the early Middle Pleistocene. Sediment, pollen and diatoms analysis of its upper part (AL2 core, $14.6 \mathrm{~m}$ ) indicates two temperate phases marked by high lake levels, forest development and vegetation expansion. They are separated by a cold period during which lake level drops, coarse sediment input increases and steppic and xerophilous plants develop. Pollen data suggests that this sequence belongs to the upper part of the Cromerian complex. These results are in agreement with the $557 \pm 3 \mathrm{ka}( \pm 12 \mathrm{ka}$, including all errors ${ }^{40} \mathrm{Ar} /{ }^{39} \mathrm{Ar}$ age obtained from an interbedded tephra layer emitted by the Mont-Dore/Sancy strato-volcano and establish that this sequence probably covers the MIS 15 substages. To cite this article: J.-F. Pastre et al., C. R. Geoscience 339 (2007).
\end{abstract}

(C) 2007 Académie des sciences. Published by Elsevier Masson SAS. All rights reserved.

\section{Résumé}

Le maar d'Alleret (Massif central, France) : une séquence lacustre du début du Pléistocène moyen en Europe de l'Ouest. Le maar d'Alleret (Massif central, France) présente une longue séquence lacustre $(40,6 \mathrm{~m})$ datant du début du Pléistocène moyen. L'étude des sédiments, du pollen et des diatomées dans sa partie supérieure (carottage AL2, 14,6 m) met en évidence deux phases tempérées, marquées par de hauts niveaux lacustres, un développement de la forêt et une grande richesse de la végétation. Elles sont séparées par une période de refroidissement, marquée par une régression lacustre, des sédiments grossiers et un développement des plantes xérophiles et steppiques. Les données polliniques permettent d'attribuer la séquence à la partie supérieure du complexe Cromérien. Ces résultats sont en accord avec la datation ${ }^{40} \mathrm{Ar} /{ }^{39} \mathrm{Ar}$ à $557 \pm 3 \mathrm{ka}$ ( $\pm 12 \mathrm{ka}$ incluant l'ensemble des erreurs) d'un tephra du Mont-Dore/Sancy et situent cette évolution pendant les différents

\footnotetext{
* Corresponding author.

E-mail address: pastre@cnrs-bellevue.fr (J.-F. Pastre).
} 
sous-stades du stade 15 de la chronologie marine isotopique. Pour citer cet article : J.-F. Pastre et al., C. R. Geoscience 339 (2007).

(C) 2007 Académie des sciences. Published by Elsevier Masson SAS. All rights reserved.

Keywords: Lacustrine sedimentation; Tephrochronology; Early Middle Pleistocene; Palynology; Diatoms; Massif Central; France

Mots clés : Sédimentation lacustre ; Téphrochronologie ; Pléistocène moyen ancien ; Palynologie ; Diatomées ; Massif Central ; France

\section{Introduction}

Lacustrine maar sequences of the French Massif Central offer a major interest for the knowledge of Quaternary continental environments of mid-latitudes. Several maar craters of the eastern Velay region, southern part of the Devès (Fig. 1) yielded an exceptional palynological and palaeoclimatic sequence covering the last five climatic cycles over ca. $450 \mathrm{ka}$ $[3,28]$. However, except for the Plio-Pleistocene sequence of Senèze [9], older sequences are poorly documented. As a consequence, the Lower and early Middle Pleistocene bioclimatic successions are poorly known. The Auvergne and Velay maars offer a great potential for improving the knowledge of these periods. Their interest is reinforced by the frequency of interbedded K-rich alkaline tephras originating from

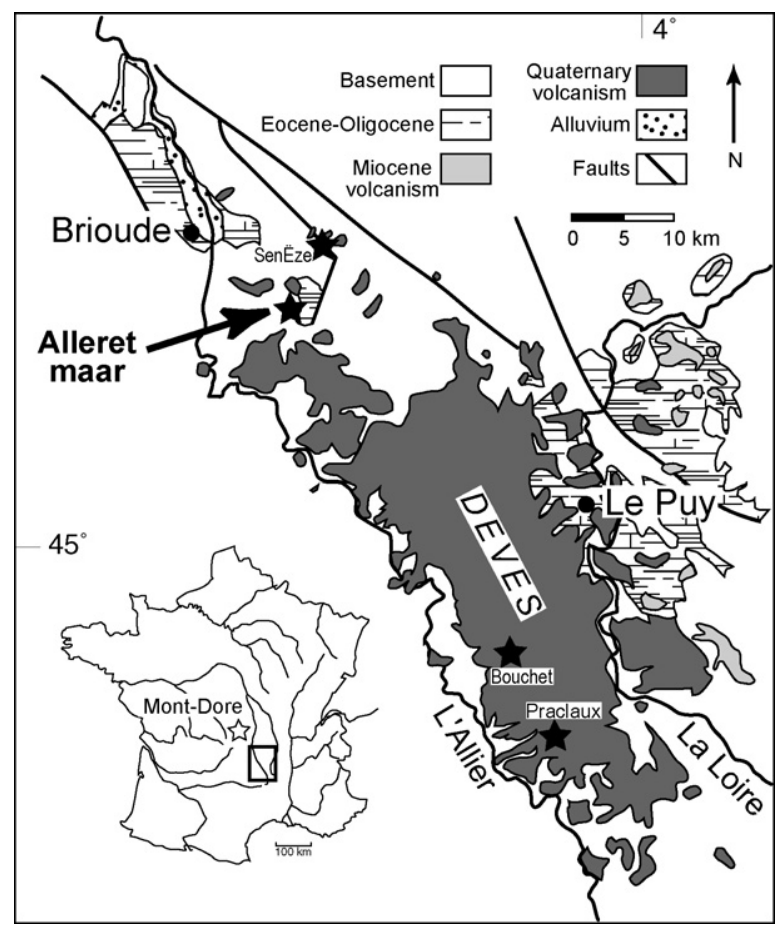

Fig. 1. Location of the Alleret maar.

Fig. 1. Localisation du maar d'Alleret. the Mont-Dore strato-volcano, providing a unique place to apply tephrochronology and use this area as a reference continental palaeoclimatic sequence (e.g., $[25,30,35])$. The Alleret maar lake fill, presented hereafter, constitutes the first documented sequence of this type for the early Middle Pleistocene in western Europe.

\section{The Alleret maar and lacustrine deposits}

The Alleret maar (Saint-Privat-du-Dragon, HauteLoire, France) is a 1500-m-wide phreatomagmatic crater located in the northern part of the Devès basaltic area, $13 \mathrm{~km}$ southeast from Brioude (Fig. 1). This maar crosscut the leptynitic gneiss of the Haut Allier metamorphic suit near the western limit of the Paulhaguet Oligocene graben [18]. A 40.6-m core (AL3 core) was recently recovered from the argillaceous lake fill. This core reached the underlying intracrateric phreatomagmatic tuff.

This paper presents the results obtained on the upper part of the sequence documented by the AL2 core $(14.6 \mathrm{~m})$. This core is located in the central part of the maar $\left(45^{\circ} 11^{\prime} 16^{\prime \prime} \mathrm{N}, 3^{\circ} 28^{\prime} 9^{\prime \prime} \mathrm{E}\right)$. Thirty-four beds (B), 1-125 cm thick, were observed (Fig. 2A). They are grouped into four stratigraphic units (U), defined on the size grade curves of sediments (Fig. 2C): UI ( -1460 to $-1360 \mathrm{~cm}, \mathrm{~B} 1-3)$ is made of silty clays; UII $(-1360$ to $-842 \mathrm{~cm}, \mathrm{~B} 4-17)$ shows alternating coarse micaceous sands and silty to sandy grey clays; UIII ( -842 to $-177 \mathrm{~cm}, \mathrm{~B} 18-28$ ) is constituted by silty clays; UIV ( $-177 \mathrm{~cm}$ to the surface, B29-34) comprises pedogeneised sandy and gravely silts.

This stratigraphic succession offers a partial correlation with bulk magnetic susceptibility (Fig. 2D). The higher values measured on UII are mainly due to detrital ferromagnesians and magnetite in the sandy fraction. Those from the upper part of UIII and the lower part of UIV are attributed to ferric illuviations. The low values of UIII are linked to clay and those of the upper part of UIV are probably related to leaching.

Total carbon percentages (Fig. 2B), attributed to organic origin, range between 0.84 and $3.52 \%$ in the 


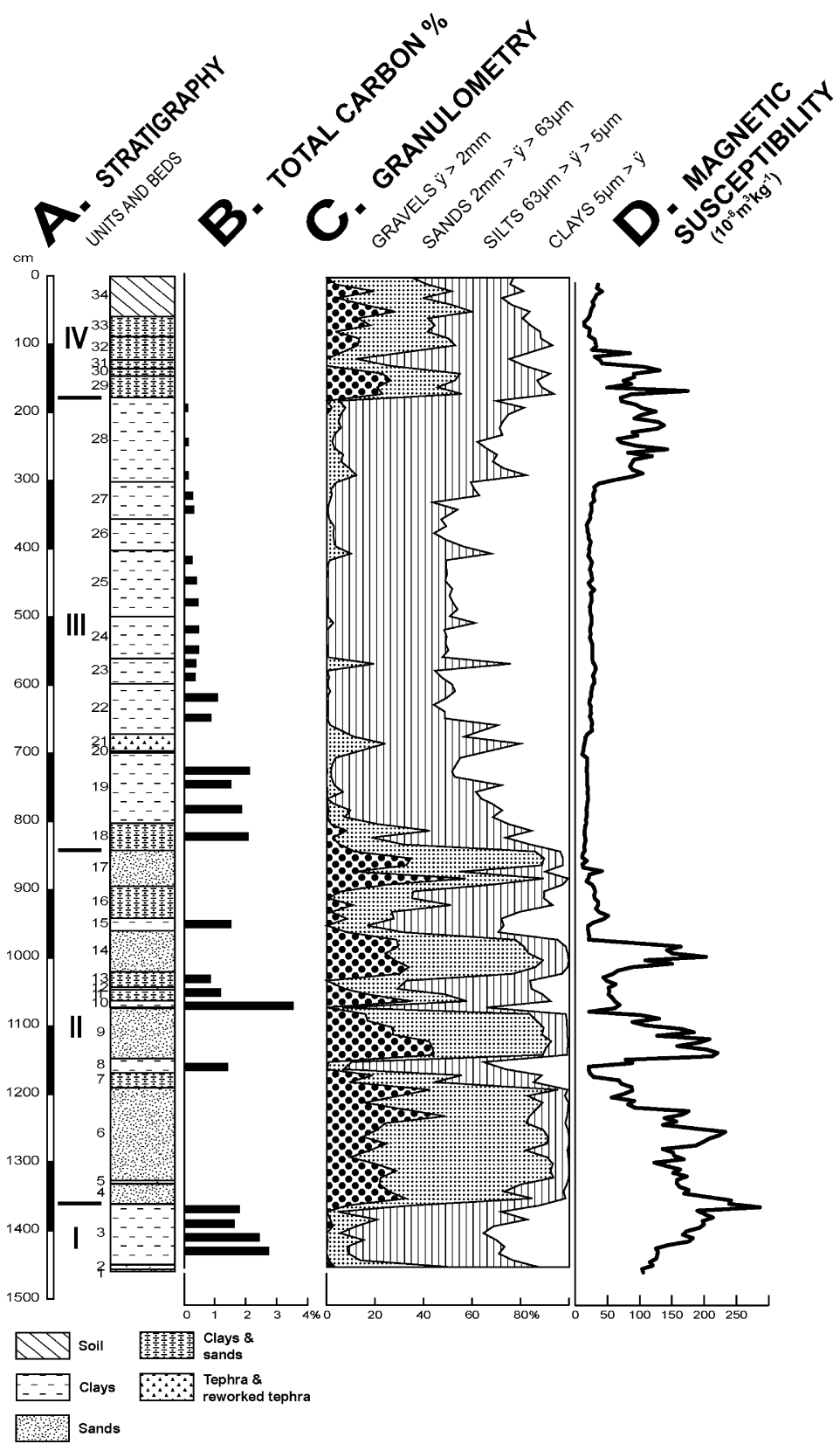

Fig. 2. Stratigraphy, total carbon (\%), granulometry and magnetic susceptibility of AL2 core.

Fig. 2. Stratigraphie, pourcentage de carbone total, granulométrie et susceptibilité magnétique du carottage AL2.

lower part of the sequence (B3-22, -1450 to $-600 \mathrm{~cm}$ ) decreasing to less than $0.5 \%(0.10-0.46 \%)$ in its upper part (B23-28, -600 to $-180 \mathrm{~cm})$. Decrease of organic productivity and/or weathering could explain this difference. $\mathrm{C} / \mathrm{N}$ ratios, mostly comprised between 6 and 12 , probably indicate an algal source for organic matter.

The sandy fraction is dominated by quartz and feldspars, attributed to the surrounding metamorphic basement. It also includes some other metamorphic minerals (biotite, amphiboles, garnet and staurotide), several volcanic and mafic minerals originating from the surrounding base-surge tuffs of the maar (olivine, orthopyroxenes and chrom-diopside) and some allochtonous volcanic minerals reworked from tephras emitted from the Mont-Dore/Sancy strato-volcano located $60 \mathrm{~km}$ to the northwest (Fig. 1). The latter ones show a typical stratigraphic distribution. In the 


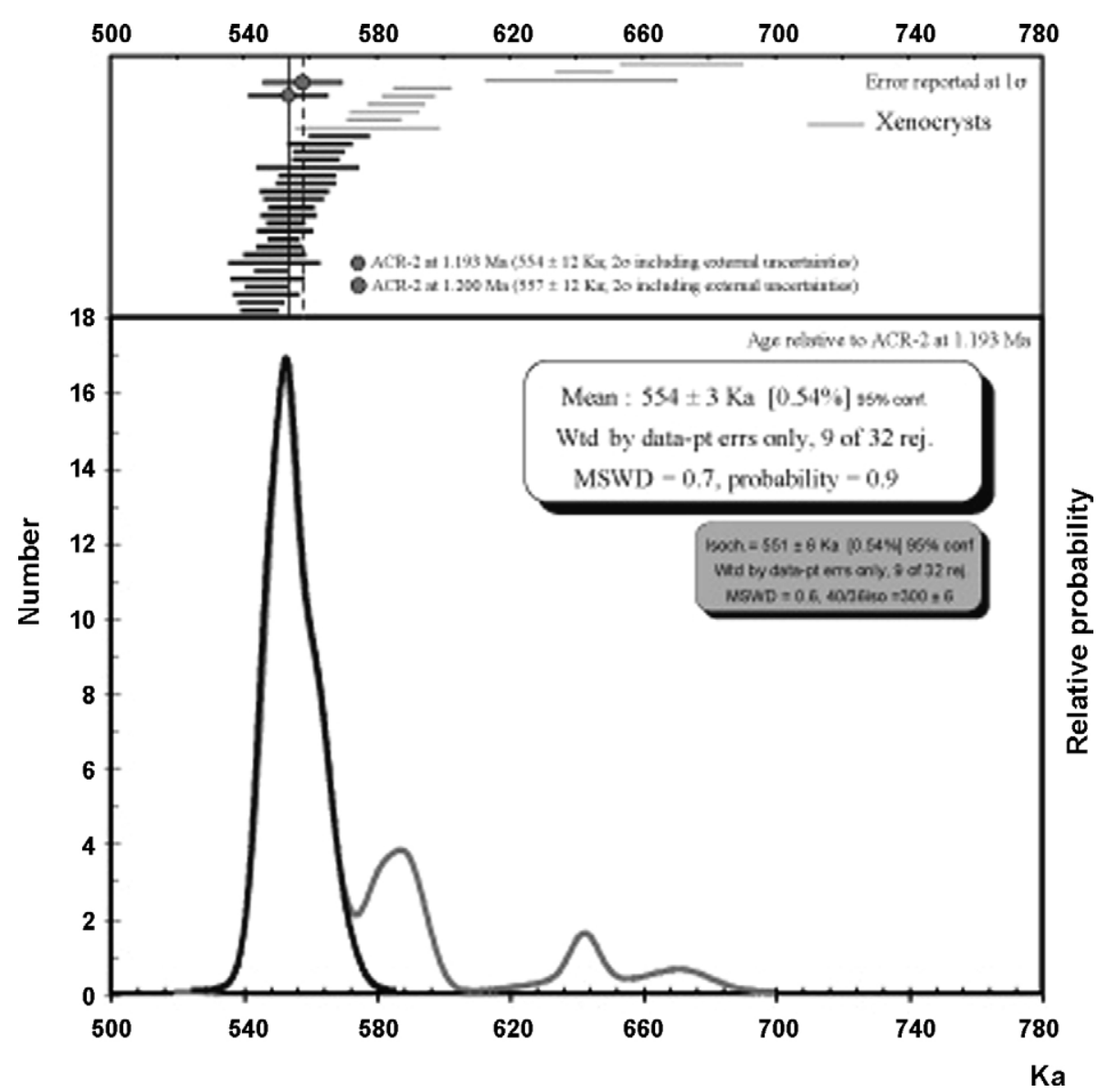

Fig. 3. Probability diagram of ${ }^{40} \mathrm{Ar} /{ }^{39} \mathrm{Ar}$ single-grain analysis.

Fig. 3. Diagramme de probabilité des âges ${ }^{40} \mathrm{Ar} /{ }^{39} \mathrm{Ar}$ sur monograin.

lower part of the fill (B4, 6, 9, 14), brown amphiboles, green clinopyroxenes (augite/diopside) and sphene occurrence indicate the progressive reworking of a previous pyroclastic fall. In B17, sphene abundance is related to the reworking of a contemporary tephra fall. Its absence as an in situ layer in the core is attributed to an erosional hiatus, accrediting the conditions prevailing in UII.

This succession is clearly linked to environmental conditions and related to the evolution of the lake. On one hand, the silty-argillaceous beds of UI and UIII correspond to lacustrine decantation facies deposited under a permanent water column. On the other hand, the alternation of gravely sands and clayey silts in UII indicates significant fluctuations of lake level, interrupted by sedimentation hiatus. In this central part of the palaeolake, temporary water-free periods allowed a wash transit of coarse material originating from the littoral deposits or from the crater slopes. The contrast between a quiet fine lacustrine deposition related to temperate conditions (UI and III) and a coarse detrital sedimentation correlative of low lacustrine levels and climatic deterioration (UII) can be underlined. The upper facies of UIV (B29-34) are interpreted as superficial washed beds contemporaneous with the erosion of the upper part of the lake fill, which occurred after sedimentation. The associated soil-horizon Bts results probably from a multiphased pedogenesis soil formation, which lasted perhaps during several interglacial periods.

\section{The tephra of unit III: type, origin and ${ }^{40} \mathrm{Ar} /{ }^{39} \mathrm{Ar}$ laser fusion dating}

An undisturbed tephra was identified at $700-\mathrm{cm}$ depth in the UIII unit (B20, $2 \mathrm{~cm}$ thickness, Fig. 2A). It is covered by reworked 'tephric' layers mixed with clay $(\mathrm{B} 21,25 \mathrm{~cm})$. The selective weathering of the cindy matrix has only preserved the mineral content. It is composed of numerous alkali feldspars (sodic sanidine- 
anorthoclase $\mathrm{Ab}_{53-65}-\mathrm{Or}_{23-45}-\mathrm{An}_{3-10}$ ), mainly associated with biotite and sphene. Other minerals (apatite, brown amphiboles, green and brown clinopyroxenes, zircons and $\mathrm{Fe}-\mathrm{Ti}$ oxides) are poorly represented. This paragenesis is typical of several pyroclastites from the Mont-Dore strato-volcano [25] and can be attributed here to its youngest member: the Sancy (1-0.25 Ma, [25]). When compared to unweathered tephras, its chemical composition indicates a relatively welldifferentiated trachytic composition (differentiation index $>80,[25])$. This tephra provides a useful tielayer dated using the single-grain laser fusion ${ }^{40} \mathrm{Ar} /{ }^{39} \mathrm{Ar}$ method.

Around $100 \mathrm{~K}$-feldspar grains along the flux standard ACR-2 (1.193 $\pm 0.01 \mathrm{Ma}, 2 \sigma,[24])$ were irradiated for $1.5 \mathrm{~h}$ at the CLICIT facility (Oregon State TRIGA Reactor, USA). After irradiation, 32 grains were individually fused with a $\mathrm{CO}_{2}$ laser (Synrad). The argon isotopic composition was measured with a MAP 215C mass spectrometer at the BGC laboratory, CA, USA (see [29] for details on sample loading and $\mathrm{Ar}$ analysis). The complete dataset, including neutron fluence $(J)$ calculated using the Steiger and Jaeger decay constants for potassium [34], nucleogenic interferences from $\mathrm{K}$ and $\mathrm{Ca}$ isotopes as well as mass discrimination, is available online as supplementary material.

The results are presented in Fig. 3 as a probability diagram. The upper part of Fig. 3 shows individual grain age ( $1 \sigma$ uncertainty). The wide range of ages obtained corresponds to a mixture of primary crystals and older xenocrysts. Such complexity is expected; it proves once again that the multi-grain approach could lead to confusing results by mixing grains of various eruptions. The youngest homogeneous population, with a probability curve close to a Gaussian, corresponds to the deposition age. We obtained an age of $554 \pm 3 \mathrm{ka} \mathrm{(} 2 \sigma$ internal error, MSWD: 0.7, 23/32 grains). The uncertainty reported above excludes the error due to the ${ }^{40} \mathrm{~K}$ decay constants (ca. $2.1 \%$ ), which corresponds to a total uncertainty of $12 \mathrm{ka}$. The isochron age is indistinguishable from the weighted mean age given above and displays, within error, atmospheric ${ }^{40} \mathrm{Ar} /{ }^{36} \mathrm{Ar}$ ratios excluding the possibility of an excess argon component.

This tephra takes place during the middle part of the Sancy pyroclastic activity [25] and it is chronologically close to the Neschers pumice flow ${ }^{40} \mathrm{Ar} /{ }^{39} \mathrm{Ar}$ dated $580 \pm 20 \mathrm{ka}$ [21]. However, as age control of both marine sediments and ice core palaeoclimatic proxies is based on orbital tuning method, we recalculate our age to $557 \pm 12 \mathrm{ka}$ (Fig. 3) according to FCs at $28.20 \mathrm{Ma}$ [see 17 for explanations] (ca. 1.20 Ma for ACR-2) to facilitate the comparison between our absolute age and these records.

\section{Pollen analysis}

Pollen samples were extracted only from clay and sandy-clay beds. Among the 66 samples analysed, eight at the top of the sequence $(-275$ to $-181 \mathrm{~cm})$ were pollen-sterile. The sample preparation technique followed standard palynological procedures [11] (HF, hot $\mathrm{HCl}$ and $\mathrm{KOH}$ ). The residue was mounted unstained in glycerol. Counting was undertaken at $\times 250$ and $\times 1000$ (oil immersion) magnifications. Pollen concentration was estimated using the volumetric method [7]. Pollen percentages are based on a main pollen sum that excludes spores, unknown and indeterminable types. For this pollen sum, at least 400 pollen grains were counted, with a minimum of 100 pollen grains without dominant taxa and 20 pollen taxa.

A total of 130 taxa were identified in the pollen analysis, among which 119 were Gymnosperms and Angiosperms. This variety suggests a rich and diversified herbaceous flora, possibly reflecting mountain environment impact, such as observed at Ceyssac [1]. Moreover, the most diversified pollen zones (AllC21, AllC2-6, AllC2-7) also show the maximum pollen concentration values (respectively, between 90,910 and 521,$905 ; 186,364$ and $1,086,667 ; 93,334$ and 316,250 grains per gram).

Nine pollen zones have been identified (Fig. 4). Pollen zone AllC2-1 is dominated by deciduous Quercus, Carpinus betulus types, Pinus, associated with Abies, Alnus, Corylus, Ulmus and Fagus. Acer, Hedera, Carpinus orientalis types, Fraxinus, Tilia, Salix, Myrica, Taxus are regularly observed and isolated grains of Pterocarya, Celtis, Nyssa and Zelkova types are recorded. Herbaceous elements show a high diversity (up to 31 taxa), with Poaceae being the most abundant. Decrease in forest elements together with increase in Poaceae begin in pollen zone AllC2-1. This decrease continues throughout pollen zone AllC2-2, where it is related to the disappearance of Pterocarya, Celtis, Nyssa and Zelkova types and to an increase in steppic pollen (Amaranthaceae-Chenopodiaceae type, Artemisia) and xerophytes-heliophilous elements (Asteroidae type, Cichorioidae type, Caryophyllaceae, Plantago). This latter evolution occurs at the clay bed (B3)/sand beds (B4-17) transition.

The record of a deciduous forest phase displaying a high diversity may be correlated with an interglacial period. Forest reduction (AllC2-2) immediately pre- 


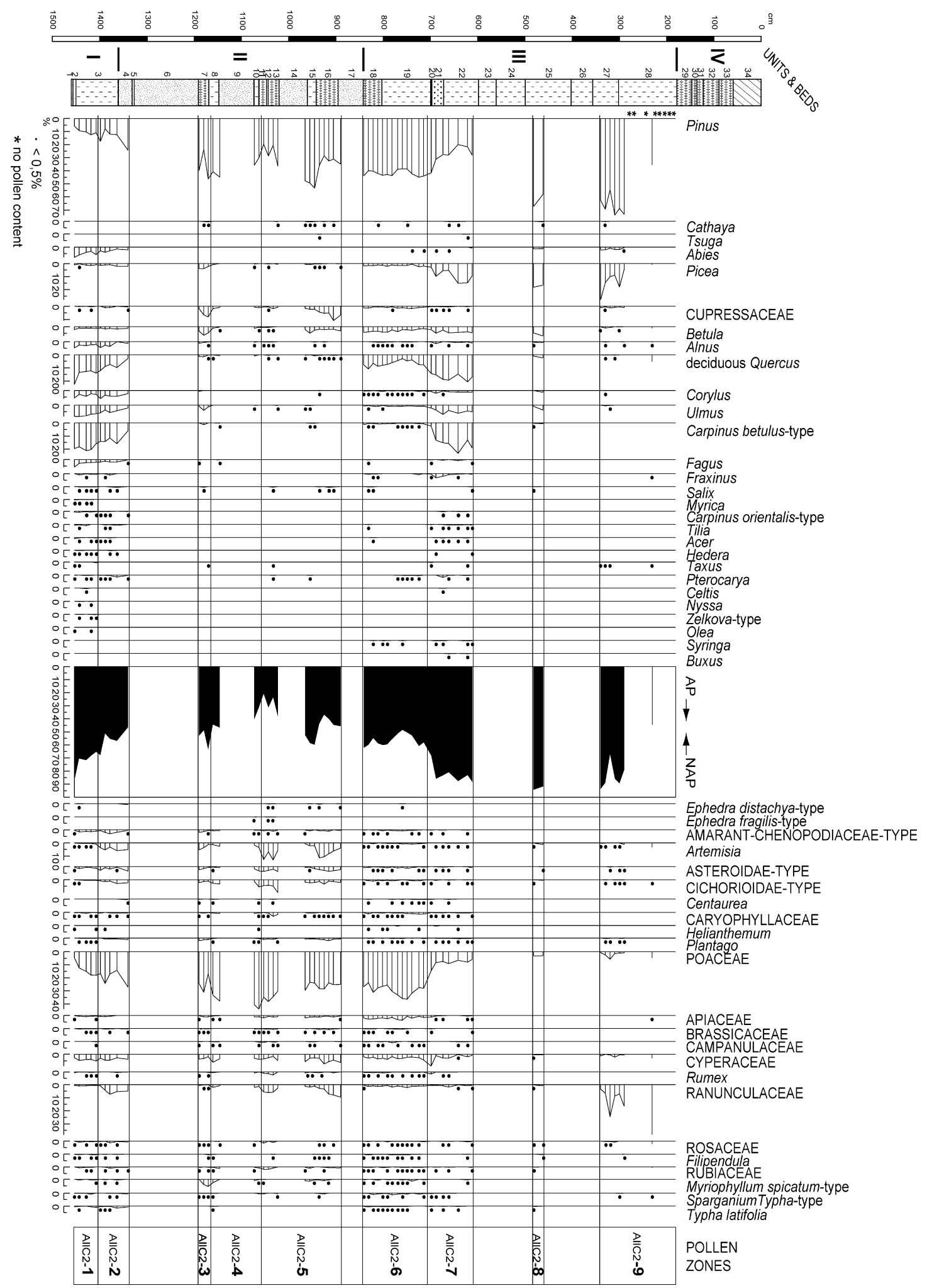

Fig. 4. Pollen diagram.

Fig. 4. Diagramme pollinique. 
ceding the sand beds (detritic input) suggests a climatic deterioration.

Pollen zone AllC2-3 is characterized by high percentages in Pinus; in the meantime, Picea, Cupressaceae, Betula, deciduous Quercus and Ulmus values are below $10 \%$. This pollen zone, reflecting a climatic improvement after the stadial conditions during the B6 sand deposition, can be considered as corresponding to an interstadial.

Poaceae maximum, low values of steppic and xerophytes-heliophilous elements and Pinus as the only arboreal taxa compose the specific signature of pollen zone AllC2-4. It suggests a landscape dominated by sparse steppic vegetation responding to dry and cold climate conditions during a stadial period.

In pollen zone AllC2-5, maxima in steppic (Ephedra, Amaranthaceae-Chenopodiaceae type, Artemisia) and xerophytes-heliophilous elements together with the decrease in Poaceae percentages suggest an open landscape quite similar to a steppe dominated by Artemisia and Poaceae [8,20]. In addition, Pinus, Cupressaceae and Betula develop. Apart from isolated pollen grains of Alnus, deciduous Quercus, and Ulmus, no mesothermic tree is recorded. The presence of Cathaya is regularly noted. This pioneer vegetation development indicates a climatic improvement, with increase of temperature and precipitation, even though climatic conditions remain rigorous.

Pollen zone AllC2-6 shows an increase in AP values, mainly deciduous Quercus, while Picea, Alnus, Corylus, Ulmus and Carpinus betulus types continuously display low percentages. Sporadic occurrences of Pterocarya and Syringa are recorded. Percentages of Pinus, Betula and Poaceae are stable, whereas Cupressaceae, steppic and xerophytes-heliophilous elements display an important decrease. As in the pollen zone AllC2-1, herbs are extremely diversified (between 23 and 32 herbaceous taxa), but values for each taxon do not exceed $1 \%$. This variety corresponds to the highest pollen concentration from the whole sequence.

Pollen zone AllC2-7 starts with the tephric layer B21. Pollen spectra are characterized by the increase in arboreal taxa percentages: mainly deciduous Quercus, Ulmus, Carpinus betulus types, Picea as well as, to a lower extent, Betula, Corylus and Fraxinus. Carpinus orientalis type, Fagus, Tilia, Acer, Pterocarya and Syringa are regularly recorded. Occurrence of Celtis and Buxus is observed only in this zone. As in the previous pollen zone, herbaceous elements are much diversified, with Poaceae still dominant, in spite of their decreasing percentages.
The pollen zones AllC2-6 and AllC2-7 succession reflects an important climatic change, which generated the regional development of deciduous Quercus and the expansion of mesothermic taxa at the expense of previous steppic formations (AllC2-6). High percentages and diversity for mesophilous elements during the maximum forest expansion (AllC2-7) suggest that this forest development occurred during an interglacial period.

In pollen zones AllC2-8 and AllC2-9, the AP maxima are due to maximal percentages of Pinus and Picea. Betula, deciduous Quercus and Ulmus are still recorded in AllC2-8; in AllC2-9, they almost disappear, while the lake is colonized by Ranunculaceae, indicative of a low water level. This altitudinal coniferous forest development with Pinus and Picea probably indicates the end of the interglacial period.

In conclusion, the pollen record of the Alleret lacustrine sequence allows us to recognize two forest formations (AllC2-1 and 2; AllC2-6 and 7). The expansion and variety of mesophilous taxa, together with pollen concentrations maxima, allow us to correlate these forest developments with two interglacial periods. The vegetation dynamics still require more data, especially because the forest decline is difficult to characterize at the end of the interglacial periods, because of the impoverishment in pollen content. However, some remarks can be made about the forest floristic composition. Both forest formations are characterized by the dominance of deciduous Quercus and Carpinus betulus types. The study of some other tree taxa, represented by low percentages, allows us to apprehend their history, mainly their disappearance or their persistence, during the Middle Pleistocene in the French Massif Central. Pterocarya, which occurs in the Alleret sequence, is never recorded in the French Massif Central after MIS 11 (Praclaux interglaciation, [27]). In parallel, the occurrence of Celtis during MIS 11 tends to show an evolution similar to that of Pterocarya; although Celtis is absent from the Praclaux interglaciation, it is recorded in the Vercors region during the $\mathrm{La}$ Côte Interglacial, correlated with the MIS 11 and the Holsteinian period [2]. Nevertheless, the importance of Carpinus betulus and the high diversity of herbaceous elements associated with the forest formations in the Alleret lacustrine sequence distinguish them from that of the Praclaux interglacial.

On the other hand, Nyssa and Zelkova, present only in the pollen zone AllC2-1, have been recorded until now in some scarce Early Pleistocene pollen data from the French Massif Central [1,6,9]. This observation is also valid for Cathaya, Tsuga and Syringa, which occur 


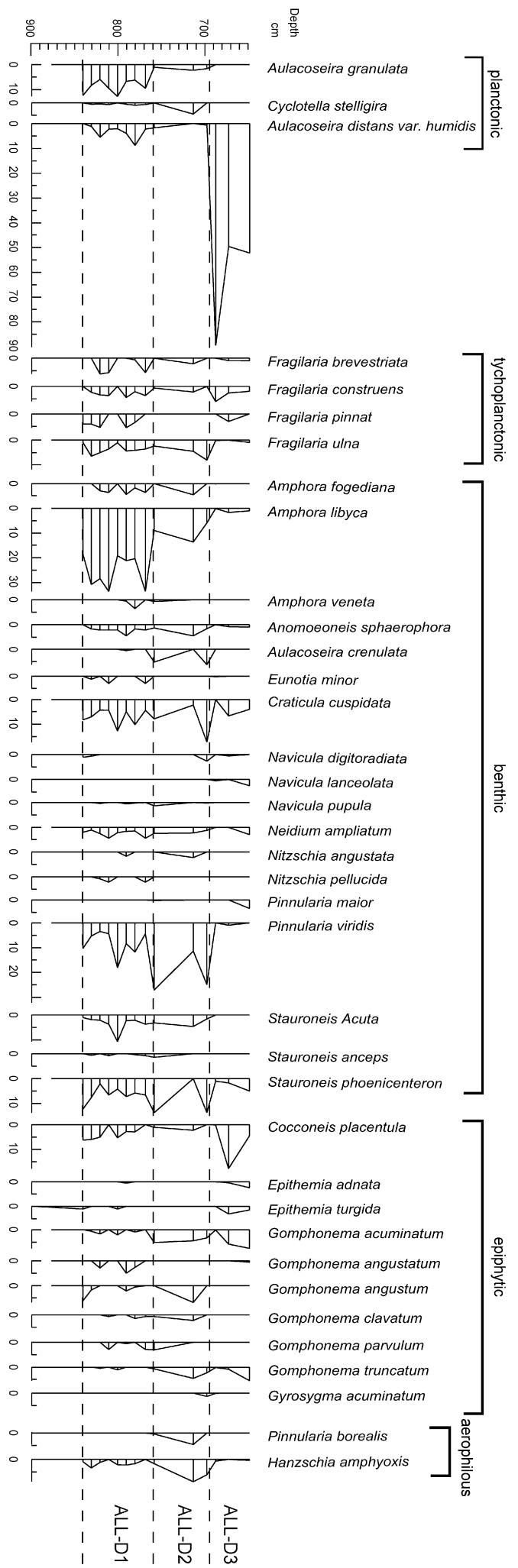

Fig. 5. Diatom diagram.

Fig. 5. Diagramme des diatomées. in the pollen zones AllC2-6 and AllC2-7. However, the flora identified in the Alleret sequence does not comprise several other taxa found in the Early Pleistocene pollen records of the Massif Central (for example, Keteleeria, Eucommia, Hamamelidaceae, Carya, Parthenocissus).

All these results allow attributing the deposition of the Alleret lacustrine sequence to the upper part of the Cromerian complex as defined in northwestern Europe $[38,39]$. This interpretation is confirmed by the tephra dating.

\section{Diatom analysis}

The diatom study was performed on 48 spectra subsampled from -1455 to $-650-\mathrm{cm}$ depth. The frustules contained in the basal part of this sequence are almost entirely dissolved, except in two samples at -1455- and -1050-cm depth. Palaeolimnological reconstruction was thus possible from samples collected throughout the part of the sequence extending from -842 to $-650 \mathrm{~cm}$ (Fig. 5).

At $-1455 \mathrm{~cm}$, the diatom assemblage is exclusively composed of Aulacoseira distans var. humilis. This species is typical of a shallow lake environment with relatively mild or warm water temperatures [12].

At $-1050 \mathrm{~cm}$ and throughout the AL-D1 zone, assemblages are characterized by the dominancy of typically benthic taxa (Amphora libyca, Navicula cuspidata, Pinnularia viridis, P. Borealis and Stauroneis phoenicenteron). A few planktonic species, like Aulacoseira granulata and Cyclotella stelligera, are also present in these assemblages, indicating a relatively low water level and milder temperatures, which are attested to by the presence of Boreo-Alpine taxa (small forms of Fragilaria, P. Borealis and A. Libyca) [13,19,22,23].

The AL-D2 zone is marked by the increase of species capable of supporting temporary emersion (Hantzschia amphyoxis, $P$. Borealis) and the extinction of the typical planktonic taxa described above. This figure suggests the contraction of the water body and the extension of a shallow marshy environment.

After the deposition of a tephra, the onset of the ALD3 zone at $-715 \mathrm{~cm}$ is characterized again by the spreading of Aulacoseira distans var. humilis, which accounts for $90 \%$ of the diatom sum. Meanwhile, the percentage of $A$. distans slightly decreases until $-650 \mathrm{~cm}$, in parallel with the renewed increase of those of the benthic taxa described above. These trends reflect a dramatic rise in the water level, which is to be related as well to an increase in available moisture as to a climatic warming. 


\section{Discussion}

Sediment, pollen and diatom analyses of core AL2 agree when characterizing the main environmental conditions of the Alleret maar's upper lacustrine sequence. They indicate a shallow lake, probably close to the end of its life. The characteristics of the uppermost part of the sediment fill at the level of today's water exsurgence (ca. $600 \mathrm{~m}$ a.s.1.) are also in accordance with end facies of a lake phase. The relatively plane topography of the bottom and the absence of topographic unconformity agree with a moderate erosion of this sequence.

From a general point of view, fine-grained beds can be related to forest development and high lake levels, while coarse-grained beds are correlated with sharp vegetal cover decrease, lake-level lowering, or even lake disappearance. These phases are respectively attributed to temperate conditions related to interglacial periods (units I and III), or to more or less cold conditions related to the stadial or the interstadial (UII).

The $557 \pm 12$-ka age obtained for the Mont-Dore/ Sancy tephra interbedded in UIII confirms the pollen data suggesting that the sequence belongs to the upper part of the Cromerian complex of the northern Europe chronology. This dating allows us to give an age to the UIII deposition, probably during the late period of the isotopic stage 15 (MIS 15). However, the continuation of temperate conditions shown by the forest expansion in the overlaying beds (pollen zones 7-9) indicates that the tephra was deposited before the MIS 15/14 transition. This however, suggests a noticeable discrepancy in age compared with the currently most recent proposed age for transition between MIS 15 and MIS 14 in both ice and marine records (ca. $564 \mathrm{ka}$ $[10,16,33])$. This discrepancy cannot be solely explained by the underestimation of the ${ }^{40} \mathrm{~K}$ decay constants. Finally, as no absolute uncertainty is usually given for astronomically tuned based palaeoclimatic records (ca. ice core or marine sediments proxies), considering the complexity involved in such comparison and the fact that we present only one absolute age, a discussion on the meaning and/or origin of this discrepancy remains hazardous at that time.

Unit II, which is characterized by alternations of gravely sands and sandy silts, probably corresponds to the incomplete sedimentary record of a cold period. Its hiatus can be explained either by an interruption in the lacustrine sedimentation or by the erosion and the wash of sediment on the crater margin. The brief episodes of interstratified silt deposition is probably due to sporadic improvements of the climate, generating short lacus- trine sedimentation periods, which are thus attributed to stadial (pollen zones 4 and 5) or interstadial episodes (pollen zone 3 ). These events probably occurred during substages $15 \mathrm{~b}, \mathrm{c}$ and $\mathrm{d}$. The characteristics of the pollen assemblages confirm the cold conditions prevailing during these substages $[26,38]$.

Silty clays layers in unit I are characterized by their richness in arboreal pollen (pollen zone 1) at the base of the unit, followed by an increase in steppic and xerophilous herbs (pollen zone 2). They probably correspond to the upper part of substage $15 \mathrm{e}$, whose last sediment records may have been truncated before the deposition of the gravely sands of unit II.

\section{Conclusion}

The upper part of the Alleret maar lacustrine sequence covered by the AL2 core provides us with a first step to extend the palaeoenvironmental and palaeoclimatic history of the French Massif Central towards the beginning of early Middle Pleistocene. It is one of the first sequences of this type studied in western Europe. Ongoing AL3 core study (40.6 m), which shows a siltyclay-dominated filling containing seven tephra layers from the Mont-Dore/Sancy in its lowest part, will improve this record, which is a key sequence for this period in mid-latitude areas. Future studies will allow us to compare the Alleret sequence with other long continuous European pollen records [4,5,14,15, $31,32,36,37]$ and to correlate with marine records in order to improve chronology for vegetation changes.

\section{Acknowledgements}

We are grateful to the two anonymous reviewers for valuable suggestions that improved the manuscript.

\section{Appendix A. Supplementary data}

Supplementary data associated with this article can be found, in the online version, at doi:10.1016/ j.crte.2007.09.019.

\section{References}

[1] D. Ablin, Analyse pollinique des dépôts lacustres de Ceyssac, Plio-Pléistocène du Velay (Massif central, France), Cah. Micropaleontol. 6 (1) (1991) 21-38.

[2] J.-L. de Beaulieu, U. Eicher, G. Monjuvent, Reconstruction of Middle Pleistocene palaeoenvironments based on pollen and stable isotope investigations at Val-de-Lans, Isère, France, Veget. Hist. Archaeobot. 3 (1994) 127-142. 
[3] J.-L. de Beaulieu, V. Andrieu, M. Reille, E. Grüger, C. Tzedakis, H. Svobodova, An attempt at correlation between the Velay pollen sequence and the Middle Pleistocene stratigraphy from central Europe, Quat. Sci. Rev. 20 (2001) 1593-1602.

[4] A. Ber, Z. Janczyk-Kopikowa, D. Krzyszkowski, A new interglacial stage in Poland (Augustovian) and the problem of the age of the oldest Pleistocene till, Quat. Sci. Rev. 17 (1998) 761-773.

[5] A. Bertini, Pollen record from Colle Curti and Cesi: Early and Middle Pleistocene mammal sites in the Umbro-Marchean Apennine Mountains (central Italy), J. Quat. Sci. 15 (2000) 825-840.

[6] A. Brun, Les applications de la palynologie à l'étude géodynamique du massif volcanique du Mont-Dore, thèse d'État, faculté des sciences, Paris, 1971

[7] P. Cour, Nouvelles techniques de détection des flux et des retombées polliniques : étude de la sédimentation des pollens et des spores à la surface du sol, Pollen Spores 16 (1) (1974) 103-141.

[8] P. Cour, Z. Zheng, D. Duzer, M. Calleja, Z. Yao, Vegetational and climatic significance of modern pollen rain in northwestern Tibet, Rev. Palaeobot. Palynol. 104 (1999) 183-204.

[9] H. Elhaï, La flore sporo-pollinique du gisement villafranchien de Senèze (Massif central, France), Pollen Spores 11 (1) (1969) 127-139.

[10] EPICA community members, Eight glacial cycles from an Antarctic ice core, Nature 429 (6992) (2004) 623-628.

[11] K. Faegri, J. Iversen, Textbook of pollen analysis, fourth ed., Wiley, Chichester, 1989.

[12] F. Gasse, East African Diatoms: Taxonomy, Ecological Distribution, Cramer, Stuttgart, Germany, 1986.

[13] T. Grönlund, T. Kauppila, Holocene history of Lake Soldatskoje (Kola Peninsula, Russia) inferred from sedimentary diatom assemblages, Boreas 31 (2002) 273-284.

[14] E. Grüger, Palynostratigraphy of the Middle Pleistocene sequence from Göttingen, Otto-Strasse, in : C. Turner (Ed.), The early Middle Pleistocene in Europes, Balkema, Rotterdam, The Netherlands, 1996, pp. 173-180.

[15] J. Hahne, The interglacial site of Hunterburg near Quakenbrück (NW Germany), in : C. Turner (Ed.), The early Middle Pleistocene in Europe, Balkema, Rotterdam, The Netherlands, 1996, pp. 181-186.

[16] J. Jouzel, V. Masson-Delmotte, O. Cattani, G. Dreyfus, S. Falourd, G. Hoffmann, B. Minster, J. Nouet, J.M. Barnola, J. Chappellaz, H. Fischer, J.C. Gallet, S. Johnsen, M. Leuenberger, L. Loulergue, D. Luethi, H. Oerter, F. Parrenin, G. Raisbeck, D. Raynaud, A. Schilt, J. Schwander, E. Selmo, R. Souchez, R. Spahni, B. Stauffer, J.P. Steffensen, B. Stenni, T.F. Stocker, J.L. Tison, M. Werner, E.W. Wolff, Orbital and millennial Antarctic climate variability over the past 800,000 years, Science 317 (2007) 793-796.

[17] K. Kuiper, F.J. Hilgen, J. Steenbrink, J.R. Wijbrans, ${ }^{40} \mathrm{Ar} /{ }^{39} \mathrm{Ar}$ ages of tephras intercalated in astronomically tuned Neogene sedimentary sequence in the eastern Mediterranean, Earth Planet. Sci. Lett. 222 (2) (2004) 583-594.

[18] B. Lasnier, J. Marchand, Carte géologique de la France au 1/50 000, feuille 2634, Brioude, BRGM, 1982.

[19] T.E. Laing, R. Pienitz, J.P. Smoll, Freshwater diatom assemblages from 23 lakes located near Norilsk, Siberia: a comparison with assemblages from other circumpolar treeline region, Diatom Res. 14 (1999) 285-305.

[20] H. Liu, Y. Wang, Y. Tian, J. Zhu, H. Wang, Climatic and anthropogenic control of surface pollen assemblages in East Asian steppes, Rev. Palaeobot. Palynol. 138 (2006) 281-289.
[21] P. Lo Bello, G. Féraud, C.M. Hall, D. York, P. Lavina, M. Bernat, ${ }^{40} \mathrm{Ar} /{ }^{39} \mathrm{Ar}$ step heating and laser fusion dating of a Quaternary pumice from Neschers, Massif central, France: the defeat of xenocrystic contamination, Chem. Geol. 66 (1987) 61-71 (Isot. Geosci. Sect.)

[22] E. Loseva, Freshwater Pleistocene assemblages of northeastern Europe, Diatom Res. 12 (1997) 263-278.

[23] A.F. Lotter, H.J.B. Birks, W. Hofman, A. Marchetto, Modern diatom, cladocera, chironomid and chrysophyte cyste assemblages as quantitative indicators for the reconstruction of past environment conditions in the Alps. I. Climate, J. Paleolimnol. 18 (1997) 395-420.

[24] S. Nomade, P.R. Renne, N. Vogel, A.L. Deino, W.D. Sharp, T.A. Becker, A.R. Jaouni, R. Mundil, Alder Creek sanidine (Acs2): a Quaternary ${ }^{40} \mathrm{Ar} /{ }^{39} \mathrm{Ar}$ dating standard tied to the Cobb Mountain geomagnetic event, Chem. Geol. 218 (2005) 315-338.

[25] J.F. Pastre, J.-M. Cantagrel, Téphrostratigraphie du Mont-Dore (Massif central, France), Quaternaire 12 (2001) 249-267.

[26] A. Prokopenko, E. Karabanov, D. Williams, M. Kuzmin, N. Shackleton, S. Crowhurst, J. Peck, A. Gvozdkov, J. King, Biogenic silica record of the Lake Baikal response to climatic forcing during the Brunhes, Quat. Res. 55 (2001) 123-132.

[27] M. Reille, J.L. de Beaulieu, Long Pleistocene pollen records from Praclaux crater, south-central France, Quat. Res. 44 (1995) 205-215.

[28] M. Reille, J.L. de Beaulieu, H. Svobodova, V. Andrieu-Ponel, C. Goeury, Pollen analytical biostratigraphy of the last five climatic cycles from a long continental sequence from the Velay region, Massif Central, France, J. Quat. Sci. 15 (2000) 665-685.

[29] P.R. Renne, C.C. Swisher, A.L. Deino, D.B. Karner, T.L. Owens, D.J. de Paolo, Intercalibration of standards, absolute ages and uncertainties in ${ }^{40} \mathrm{Ar} /{ }^{39} \mathrm{Ar}$ dating, Chem. Geol. 145 (1998) 117-152.

[30] S. Roger, C. Coulon, N. Thouveny, G. Féraud, A. Van Velzen, S. Fauquette, J.-J. Cochemé, M. Prévot, K.L. Verosub, ${ }^{40} \mathrm{Ar} /{ }^{39} \mathrm{Ar}$ dating of a tephra layer in the Pliocene Senèze maar lacustrine sequence (French Massif Central): constraint on the age of the Réunion-Matuyama transition and implications on paleoenvironmental archives, Earth Planet. Sci. Lett. 183 (3-4) (2000) $431-440$

[31] S. Rossi, Étude pollinique de la séquence lacustre pléistocène de Piànico-Sèllere (Italie), thèse, université Aix-Marseille-3 \& Università degli Studi di Milano, 2003.

[32] E. Russo Ermolli, R. Cheddadi, Climatic reconstruction during the Middle Pleistocene: a pollen record from Vallo di Diano (southern Italy), Geobios 30 (1997) 735-744.

[33] N. Shackleton, A. Berger, W. Peltier, An alternative astronomical calibration of the Lower Pleistocene timescale based on ODP Site 677, Trans. R. Soc. Edinb.: Earth Sci. 81 (1990) 251-261.

[34] R.H. Steiger, E. Jäger, Subcommission on geochronology: convention on the use of decay constants in geo- and cosmochronology, Earth Planet. Sci. Lett. 36 (1997) 359-362.

[35] A. Teulade, Téphrologie des formations cendro-ponceuses en milieux lacustres quaternaires. Méthode d'étude et applications au Massif central français (Velay) et aux Carpathes orientales roumaines (dépression de Brassov), thèse, université Aix-Marseille-2, 1989.

[36] A.M. van der Wiel, T.A. Wijmstra, Palynology of the lower part (78-120 m) of the core Tenaghi Philippon II, Middle Pleistocene of Macedonia, Greece, Rev. Palaeobot. Palynol. 52 (1987) 73-88.

[37] A.M. van der Wiel, T.A. Wijmstra, Palynology of the 112.8-197.8-m interval of the core Tenaghi Philippon III, 
Middle Pleistocene of Macedonia, Rev. Palaeobot. Palynol. 52 (1987) 89-117.

[38] W.H. Zagwijn, The beginning of the Ice Age in Europe and its major subdivisions, Quat. Sci. Rev. 11 (1992) 583-591.
[39] W.H. Zagwijn, The Cromerian Complex Stage of the Netherlands and correlation with other areas in Europe, in : C. Turner (Ed.), The early Middle Pleistocene in Europe, Balkema, Rotterdam, The Netherlands, 1996, pp. 145-172. 